\title{
Rapid primary productivity changes in one of the last coastal rainforests: the case of Kahua, Solomon Islands
}

\author{
IRENE GARONNA ${ }^{1}$, IOAN FAZEY ${ }^{2}$, MOLLY E. BROWN ${ }^{3}$ AND NATHALIE PETTORELLI ${ }^{1 *}$ \\ ${ }^{1}$ Institute of Zoology, Zoological Society of London, Regents Park, London NW1 4RY, UK, ${ }^{2}$ School of Geography and Geosciences, Irvine \\ Building, University of St Andrems, Fife KY16 9AL, UK, and ${ }^{3}$ NASA-Goddard Space Flight Center, Code 614.4, Greenbelt, MD 20771, USA \\ Date submitted: 3 June 2009; Date accepted: 25 September 2009; First published online: 14 December 2009
}

\section{SUMMARY}

The growth of human populations has many direct and indirect impacts on tropical forest ecosystems both locally and globally. This is particularly true in the Solomon Islands, where coastal rainforest cover still remains, but where climate change and a growing human population is putting increasing pressure on ecosystems. This study assessed recent primary productivity changes in the Kahua region (Makira, Solomon Islands) using remote sensing data (normalized difference vegetation index, NDVI). In this area, there has been no commercial logging and there is no existing information about the state of the forests. Results indicate that primary productivity has been decreasing in recent years, and that the recent changes are more marked near villages. Multiple factors may explain the reported pattern in primary productivity. The study highlights the need to (1) assess how accurately remote sensing data-based results match field data on the ground; (2) identify the relative contribution of the climatic, socioeconomic and political drivers of such changes; and (3) evaluate how primary productivity changes affect biodiversity level, ecosystem functioning and human livelihoods.

Keymords: MODIS (moderate-resolution imaging spectroradiometer), NDVI (normalized difference vegetation index), primary productivity, Solomon Islands, tropical forests

\section{INTRODUCTION}

Tropical forests play a disproportionately significant role in global carbon and energy cycles and are major climate regulators, providing humankind with numerous precious ecosystem services (Wright 2005; Bonan 2008). These habitats moreover support half of all described species and are thought to accommodate an even larger proportion of unknown species (Wright 2005). Pressures of growing population and economic development have led to rapid changes in tropical forest landscapes, mainly through the intensification of exploitation of ecosystem services (Wright 2005; Walker \& Salt 2006).

*Correspondence: Dr Nathalie Pettorelli Tel: +4420 74496334 Fax: +442074832237 e-mail: Nathalie.Pettorelli@ioz.ac.uk
Understanding the overall impact of anthropogenic drivers of change is a complex challenge (Wright 2005). An essential first step is to study the present status of tropical forest areas and to determine whether and how they have been changing (Alcaraz-Segura et al. 2009). The need for and importance of forest monitoring has been widely recognized by international organizations, such as the Food and Agriculture Organization (FAO) or the Intergovernmental Panel on Forests (IPF) of the United Nations (UN).

The Solomon Islands are a good example of highly forested habitat that is impacted increasingly by anthropogenic forces. The Solomon Islands are located in the tropics, north of Australia and east of Papua New Guinea in the South West Pacific, between latitudes $5^{\circ} \mathrm{S}$ and $12^{\circ} \mathrm{S}$ and longitudes $152^{\circ} \mathrm{E}$ and $170^{\circ} \mathrm{E}$ (Fig. 1). This independent nation consists of over 300 islands (FAO 2000), and has been described as being 'among the few places on earth where large tracts of coastal rainforest cover remain at the start of the 21st century' (Bayliss-Smith et al. 2003). The nation's economy and development are heavily reliant on income from exports such as timber, fish, copra, palm oil, cocoa, other agriculture products and gold (FAO 2000). The forest sector is the biggest single employer in the country (Raymond \& Wooff 2006), with logging representing $80 \%$ of the nation's total export earnings (FAO 2000). Irrespective of the impact of logging, in areas where logging has not occurred, there have been significant socioeconomic and demographic changes that are impacting coastal forests. While people have affected forests in the Solomon Islands for thousands of years (Bayliss-Smith et al. 2003), recent changes have been particularly intensive and rapid. Two main factors drive the current changes. The first is demographic: in the last decade, the population growth rate has been as high as $3.4 \%$ per annum, which is amongst the ten highest rates in Asia and in the Pacific (UNESCAP [United Nations Economic and Social Commission for Asia and the Pacific] 2005). In order to meet the requirements of this rapidly growing population, many households have started prioritizing short-term income-generating schemes, such as cash crop production (Bourke et al. 2006; Fazey et al. 2007). These land use conversions may not only result in great biomass loss, but also affect hydrological and biogeochemical processes (Feddema et al. 2005). The second factor is global anthropogenic climate change, which is beginning to have an impact on these islands (Ebi et al. 2006). Local people have observed a decrease in production of fruits on trees, which may be due to an increase in the intensity and frequency of 


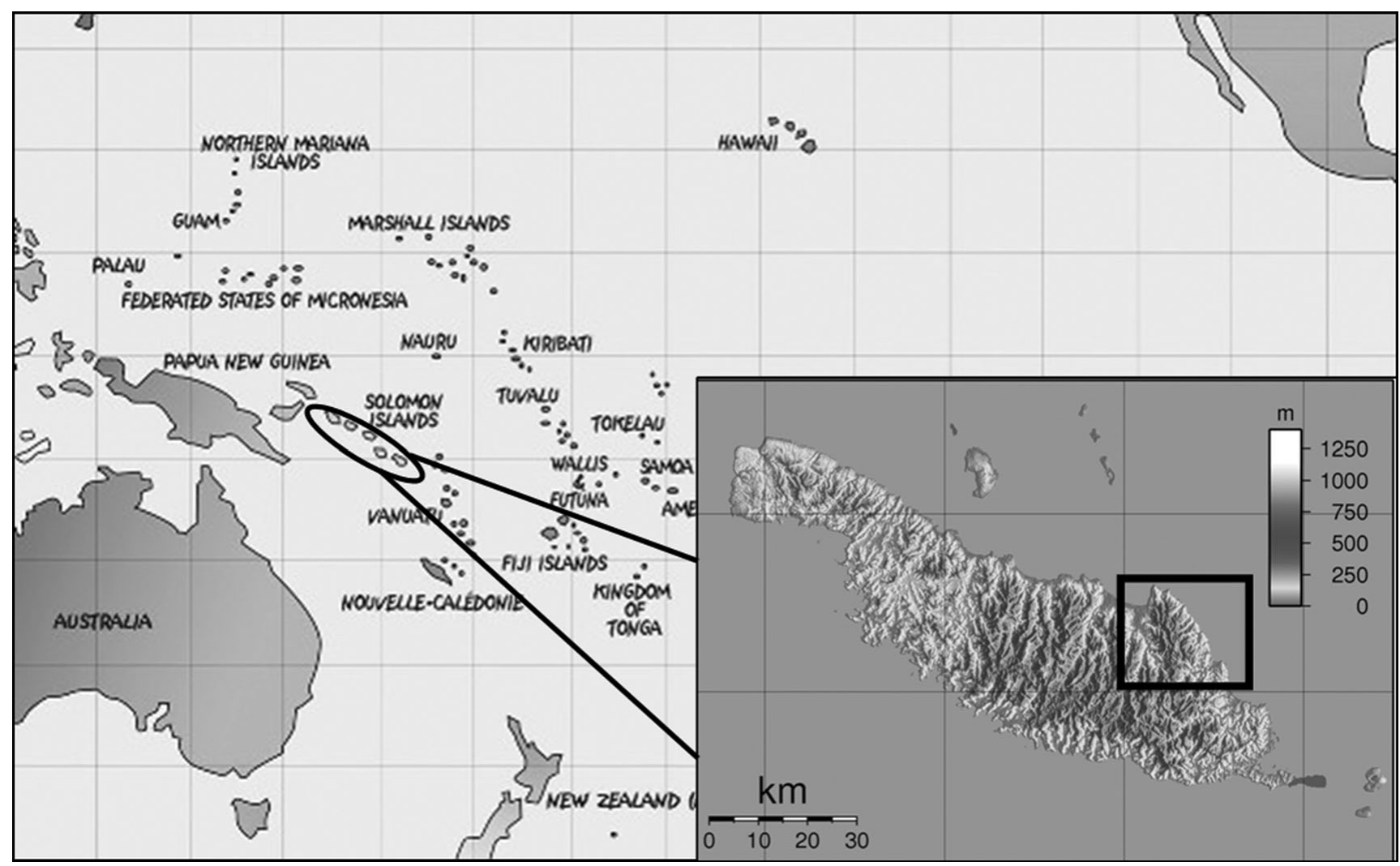

Figure 1 The Kahua region (in the small black square) is located on Makira Island, also called San Cristobal, in the Eastern Makira-Ulawa Province of the Solomon Islands. The coordinates of the delimited Kahua region extend from $162^{\circ} 0^{\prime} \mathrm{E}$ to $162^{\circ} 15^{\prime} \mathrm{E}$, and from $10^{\circ} 25^{\prime} \mathrm{S}$ to $10^{\circ} 40^{\prime} \mathrm{S}$.

rain events and the damages they cause to flowers (Fazey et al. 2007). Together, population growth and the currently low but increasing impact of climate change are thought to be having various interrelated and reinforcing consequences, namely rising pressure on land to produce more food, increasing pollution due to poor sanitation of the growing population and a switch from a traditional subsistence economy to an increasingly monetary one (made possible, in part, because of increased access to global markets; Fazey et al. 2007).

This paper aims at assessing recent vegetation changes in the Solomon Islands, focusing on primary productivity changes in a region called Kahua, located in Makira-Ulawa Province, Eastern Solomon Islands. Examination of the temporal and spatial dynamics in vegetation productivity is key to monitoring forest ecosystem distribution and functioning (Baldi et al. 2008; Alcaraz-Segura et al. 2009). In Kahua, local communities have formed a grassroots organization called the Kahua Association to try to address some of these challenges and promote more sustainable and equitable development. The organization aims to provide a more integrated approach to governance and decision-making across the 40 communities and 4500 people it represents (Fazey et al. 2007). The population growth in this region is rapid, with a doubling time of approximately $14-17$ years, and there is increasing emphasis on income-generating activities facilitated by incentives and projects introduced by various external donor agencies (Fazey et al. 2007). This study also aims to assist the Kahua Association to make informed decisions about sustainable development, by providing an initial exploration of possible primary productivity changes and how this may relate to human activity in the area.

\section{MATERIAL AND METHODS}

\section{Study area}

Kahua is located on Makira Island, also called San Cristobal, in the Eastern Makira-Ulawa Province of the Solomon Islands. Kahua lies $162^{\circ} 0^{\prime}-162^{\circ} 15^{\prime} \mathrm{E}, 10^{\circ} 25^{\prime}-10^{\circ} 40^{\prime} \mathrm{S}$ and has c. 4500 inhabitants (Fazey et al. 2007). Makira extends over $3190.5 \mathrm{~km}^{2}$ (Dahl 2004), and has a mountainous interior with peaks near 1200 metres (Mueller-Dombois \& Fosberg 1998). Most of the settlements in Makira are located along the coast. The Solomon Islands are among the wettest regions of the globe (Brookfield 1969) and the climate on Makira Island is characterized by high humidity, abundant rainfall and little annual variation in temperature (Brookfield 1969; Leary 1992). The archipelago is located near the south-west Pacific low-pressure system, which causes an abundant rainfall all year-round (Mueller-Dombois \& 
Fosberg 1998); the average annual rainfall on Makira Island is 3600-4000 mm, with no dry month (Allen et al. 2006; Appendix 1, see Supplementary material at URL http://www. ncl.ac.uk/icef/EC_Supplement.htm). Although it is well known that lowland tropical rainforest and woody vegetation dominate the Solomon Islands vegetation, there is very limited up-to-date detailed information on its composition (WSSD [World Summit for Sustainable Development] Working Group 1992): Whitmore (1969) originally distinguished three types of vegetation occurring on the Solomon Islands, namely grasslands and heaths, lowland forests and montane forests. According to the 1:50 000 vegetation maps for Makira Island compiled by the Directorate of Overseas Surveys, Tolwoth (British Solomon Islands, DOS 456), the Kahua region appears to be covered by 'forest', with 'swamps' present only by the banks of the rivers Warihito and Araghoha. Lowland forests are characterized by a high forest canopy (30-45 m tall), dominated by large trees species such as Campnosperma brevipetiolatum, Endospermum medullosum and Gmelina moluccana. Several common tree species form the top of the lowland forest canopy: Calophyllum kajemskii, Calophyllum vitiense, Dillenia salomonensis, Elaeocarpus sphaericus, Endospermum medullosum, Gmelina moluccana, Maranthes corymbosa, Parinari salomonensis, Pometia pinnata, Schizomeria serrata and Terminalia calamansanai (Whitmore 1969). The most distinctive variant of lowland rainforest exists in two small outcrops of ultrabasic rock which lie inside or at the border of the study area, characterized by being poor in tree species, mainly Casuarina papuana or Dillenia crenata (Whitmore 1969). Conversely, montane forest is described as 'very 'mossy' with the ground and tree trunks and limbs usually swathed in bryophytes up to $30 \mathrm{~cm}$ thick' (Whitmore 1969).

\section{Monitoring primary productivity changes}

Traditional field ecological data are usually not applicable to long-term or larger-scale studies aiming at monitoring vegetation at regional or national scales because of the costs and practical difficulties involved. Instead, ecologists and conservation biologists have increasingly used satellite-based data to monitor vegetation and understand mechanisms of environmental change (Pettorelli et al. 2005). Remote sensing involves deriving information about the Earth's surface by measuring the electromagnetic radiations it reflects (Tucker 1979; Campbell 2007). Amongst all the land cover information that can be derived through remote sensing, vegetation indices are combinations (through addition, subtraction, multiplication or division) of multiple spectral values that produce a quantitative measure used to infer primary productivity within a pixel (Campbell 2007). The normalized difference vegetation index (NDVI) is amongst the most intensely studied and commonly used vegetation indices (Kerr \& Ostrovsky 2003). NDVI is derived from the red:near-infrared reflectance ratio $(\mathrm{NDVI}=(\mathrm{NIR}-\mathrm{RED}) /(\mathrm{NIR}+\mathrm{RED})$, where NIR and RED are the amounts of near-infrared and red light, respectively, reflected by the vegetation and captured by the sensor of the satellite). Green leaves absorb incoming solar radiation in the photosynthetic active radiation (PAR) spectral region, drawing from this irradiance the energy needed to power photosynthesis (Jensen 2007). Conversely, green leaf molecules reflect infrared radiation, since its absorption would over-heat the plant and denature its proteins (Jensen 2007). Thus, green leaves have low high visible light absorption and high near-infrared reflectance, resulting in NDVI values close to 1 . Senescing vegetation, soil, cloud and snow will have higher near-infrared absorbance, thus driving NDVI values closer to -1 (Tucker et al. 1985; Neigh et al. 2008). Thus, such data from a range of images taken over time provide indications of change in the red and near-infrared reflectance and hence in primary productivity.

We used MODIS (moderate-resolution imaging spectroradiometer) MOD13A1 collection 5 data (Huete et al. 2002) with a pixel resolution of $250 \mathrm{~m}$. MODIS is a state-of-theart instrument on board the NASA (National Aeronautics and Space Administration) Terra satellite. NDVI values are available on a bi-monthly basis from mid-February 2000. The dataset considered thus spanned from 18 February 2000 to 18 December 2008 and the data were analysed in their native 16day compositing period. We reduced the dataset to the Kahua region coordinates (Fig. 1).

\section{Statistical procedures}

NDVI is a crude estimate of vegetation health (Goward \& Prince 1995), and its ability to monitor variation in primary productivity can sometimes be reduced (Markon \& Peterson 2002). In tropical ecosystems, the radiation reaching the satellite sensor may be contaminated by atmospheric variations such as cloud cover and smoke, and NDVI values may therefore become inexact representations of the vegetation status on the ground (Tanre et al. 1992; Achard \& Estreguil 1995); our first step was to correct for environmental noise ('smoothing') (Kerr \& Ostrovsky 2003; Pettorelli et al. 2005). We performed manual smoothing, by visualizing the data for each pixel and checking for rapid changes (of 0.3 or more from one composite to the next) in NDVI values which were followed by a rapid return to the original values. We attributed these changes to environmental noise, because factors such as water, clouds and shadow give rise to highly reduced NDVI values (Pettorelli et al. 2005). Once we had identified all contaminated values, they were replaced by the average of the previous and following values, so as to 'smooth' the annual NDVI curve for that pixel (Appendix 2, see Supplementary material at URL http://www.ncl.ac.uk/icef/EC_Supplement.htm). In order to have the same number of NDVI values per month and per pixel, we only considered the highest NDVI value occurring each month for each pixel (procedure based on the maximum value compositing; Holben 1986). Based on this new dataset (one NDVI value per pixel and per month), the average monthly NDVI value for the whole area could be determined. February and March 2000 still appeared highly contaminated 
and we discarded these data from subsequent analyses. The final dataset thus spanned from April 2000 to November 2008.

To explore any temporal patterns in the average primary productivity of the study area, we determined Spearman's rank correlation coefficient between the monthly average NDVI and the year. Average NDVI corresponded here to the average NDVI for all the 3229 MODIS pixels for the considered month, and the significance of the relationship between the average NDVI for the 12 months (JanuaryDecember) and the years (generally from 2000-2008, 20012008 for January-March, 2000-2007 for December) was tested. The threshold value considered corresponded to a unilateral test, with $\alpha=5 \%$.

To explore any spatial patterns in the distribution of primary productivity in the study area, we calculated the average Spearman's rank correlation coefficient $\left(r_{s}\right)$ between the year and the monthly average NDVI (from April 2000 to November 2008) for each of the 3229 pixels.

\section{RESULTS}

Environmental noise correction led to a significant drop in the number of pixels that could be considered for exploring spatiotemporal patterns in NDVI. Out of the 6066 pixels originally considered to be within the region of Kahua, we could only use 3229 pixels for analysis.

Average NDVI values for each month show that month-tomonth variation in the average NDVI throughout the year is low (ranging from 0.923 in May to 0.887 in October; Table 1). April and May appear to be the most productive months, with the highest NDVI and the lowest associated inter-annual variability. October and November seem to be the least productive months, with the highest associated interannual variability. Spearman's rank correlations indicated that four months (January, April, May and September) out of twelve had a significant decline in primary productivity in the Kahua region between 2000 and 2008 (Table 1).

Separate correlations for monthly averages of the NDVI of each of the 3229 MODIS pixels indicated changes in primary productivity. The average Spearman's rank correlation coefficients between the year and the monthly average NDVI for the 3229 MODIS pixels considered revealed that 2660 pixels $(82 \%)$ displayed average negative correlation coefficients, while only 569 pixels displayed positive average correlation coefficients (Fig. 2). The strongest average negative associations between years and monthly NDVI were found in the north-western part of the area (Appendix 3, see Supplementary material at URL http://www.ncl.ac.uk/ icef/EC_Supplement.htm). This area corresponds to the concentrations of villages in the more fertile and flatter flood plains of the Warihito river.

\section{DISCUSSION}

Analysis of primary productivity variation in the Kahua region sheds light on some important features of its ecosystem
Table 1 Spearman's rank correlation coefficient $\left(r_{s}\right)$ between the monthly average NDVI for the 3229 MODIS pixels considered and the year. Average is the average NDVI for all pixels for the considered month, and the significance of the relationship between the average NDVI for the 12 months (January-December) and the years (generally 2000-2008; 2001-2008 for January-March, 20002007 for December) is tested. The threshold value corresponds to a unilateral test, with $\alpha=5 \%$. ${ }^{*} p<0.05$. There was a decrease in primary productivity in January, April, May and September. There was no significant trend for the other months.

\begin{tabular}{llllcl}
\hline \hline Month & $\begin{array}{l}\text { Average } \\
\text { NDVI }\end{array}$ & $\begin{array}{l}\text { Standard } \\
\text { deviation }\end{array}$ & $\begin{array}{l}\text { Number of } \\
\text { years }\end{array}$ & $r_{s}$ & Threshold \\
\hline January & 0.908 & 0.015 & 8 & -0.809 & $0.619^{*}$ \\
February & 0.906 & 0.015 & 8 & -0.357 & 0.619 \\
March & 0.917 & 0.013 & 8 & 0.048 & 0.619 \\
April & 0.922 & 0.007 & 9 & -0.783 & $0.583^{*}$ \\
May & 0.923 & 0.007 & 9 & -0.633 & $0.583^{*}$ \\
June & 0.914 & 0.015 & 9 & 0.333 & 0.583 \\
July & 0.915 & 0.012 & 9 & 0.1 & 0.583 \\
August & 0.916 & 0.008 & 9 & -0.333 & 0.583 \\
September & 0.904 & 0.012 & 9 & -0.6 & $0.583^{*}$ \\
October & 0.887 & 0.019 & 9 & 0.25 & 0.583 \\
November & 0.896 & 0.022 & 9 & 0.15 & 0.583 \\
December & 0.912 & 0.008 & 8 & 0.143 & 0.619 \\
\hline \hline
\end{tabular}

ecology. First, high NDVI values were reported throughout the year, as expected in a tropical forest area (see Xiao et al. 2006). Second, annual maximums of NDVI are more frequent during the driest months May-September (Table 1; Appendix 1, see Supplementary material at URL http://www.ncl.ac.uk/icef/EC_Supplement.htm). This is consistent with Saleska et al. (2007) who concluded that reduced rainfall resulted in higher primary productivity in a South American wet tropical region. More light during the dry season should indeed result in higher NDVI values, particularly in extremely cloudy tropical forest ecosystems such as that found in the Solomon Islands. Third, nearly half of the original pixels within the Kahua area could not be used, demonstrating cloud contamination can be a tangible obstacle to the analyses of NDVI time series in tropical regions. The year-round abundant rainfall and high humidity characterizing the climate of the Solomon Islands, coupled with the occurrence of high altitude areas, makes the Kahua region particularly difficult to study using weatherdependent remote sensing data. Finally, the results indicate a decreasing trend in primary productivity in recent years in the Kahua region. This is important because information on the state of vegetation in regions such as Kahua, where no intensive commercial logging is occurring and no logging licences exist (Appendix 4, see Supplementary material at URL http://www.ncl.ac.uk/icef/EC_Supplement.htm), is still lacking. While the decrease in primary productivity seems to be generalized to all parts of Kahua, we identified a 'hotspot' region of change (in the north-west).

What can explain the 2000-2008 trend in primary productivity (as indexed by NDVI)? Land-use intensification 


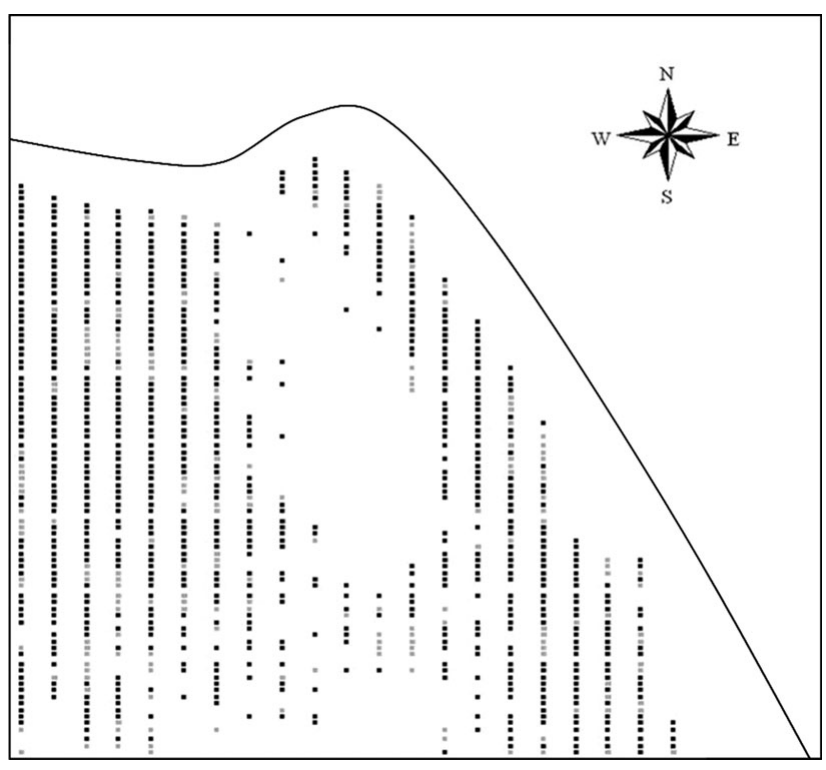

Figure 2 Average Spearman's rank correlation coefficient $\left(r_{s}\right)$ between the year and the monthly average NDVI (April 2000-November 2008) for the 3229 MODIS pixels considered (area corresponds to square area delineated on Makira island in Fig. 1). Black squares (2660 pixels) represent pixels where the average correlation was negative, while grey squares (569 pixels) represent pixels where the average correlation was positive. Average negative correlations spanned from -0.00008 to -0.634 (average $=-0.14$ ), while positive correlations spanned from 0.0005 to 0.506 (average $=$ 0.06). The blank central area of Kahua corresponds to the location where most of the pixels were removed during smoothing. This central area is higher-altitude cloud forest (see Fig. 1), reaching nearly 1000 metres, where the incidence of cloud cover is very high. The coastal pixels as well as some pixels in the northern and southern areas were also removed, due to the high level of contamination.

is one possibility, but there are others. There are first the occasional effects of tropical cyclones on forests, which can cause local deforestation and/or reduced primary productivity. Major tropical cyclones occurred during 2000 2008, including Zoe (December 2002), Gina (June 2003) and Beni (January 2003) (see URL http://reliefweb.int); other natural disasters during this period include a tsunami in April 2006. To our knowledge, there are no reports of significant damage on the East Coast of Makira generated by these disasters. The ethnic tensions and failing state conditions in Solomon Islands during 1999-2003 (Raymond \& Wooff 2006) might then have corresponded to a period of paralysis when it comes to trading, which could have resulted in a lower rate of forest disturbances. This factor could be a reason for the early 2000s generating a base-line of forest disturbance (as measured by NDVI) that was low compared to the situation in the late 2000s. The Solomon Islands are finally subject to major fluctuations in rainfall in response to El Niño-Southern Oscillation (ENSO) cycles: El Niño conditions are usually associated with below normal rainfall in most parts of the Solomon Islands. Freely available and online ENSO data show that El Niño conditions prevailed in 2002-2004, while La Niña conditions (extremely wet conditions in the Solomon Islands) prevailed in 2000, from mid-2005 to mid-2006 and from mid-2007 to the end of 2008 (for more information, see URL http://www.bom.gov.au/climate). If higher rainfall occurred during the driest months as a result of La Niña conditions dominating the second half of the monitoring period, then higher cloud contamination could explain our results. Yet we could not find any relevant available data on precipitations for the region or the island to assess this possibility.

Why do we report a significant trend in NVDI for only four months out of twelve? Several sources of variation could be the cause. First, NDVI is cloud sensitive and cloud cover in the region of Kahua can vary from one month to another (Appendix 1, see Supplementary material at URL http://www.ncl.ac.uk/icef/EC_Supplement.htm). Clouds are more likely to bias NDVI estimates in wet months than in dry months, which means that the chances of capturing any trend during wet months are low. If climate is driving the reported patterns in primary productivity and if higher rainfall occurred during the driest months as a result of $\mathrm{La}$ Niña conditions dominating the second half of the monitoring period, chances of capturing a negative trend in primary productivity during the driest months were high. Finally, the quality of the information regarding primary productivity variation encompassed in NDVI values varies with the spatial location and, in particular, NDVI is known to have only a weak ability to detect primary productivity variation in very dense canopies (Huete et al. 2002; Pettorelli et al. 2005). If there is seasonality in the factor driving primary productivity changes (such as land use for example), months associated with the highest intensity will have a higher probability of capturing a trend (since NDVI differences between used and non-used pixels are maximized during these months).

Could the trend reported be only the result of random climate-driven noise in primary productivity? This seems unlikely. First, if the trend reported was only the result of random noise in primary productivity, there should be by chance as many pixels that have an average negative coefficient as pixels that have an average positive coefficient. Clearly, this is not the situation; 2660 out of $3229(\sim 82 \%)$ pixels had an average negative correlation coefficient. Moreover, if the trend reported was only the result of climate-driven noise in primary productivity, there should be no association between village distribution and primary productivity decreases (Appendix 3, see Supplementary material at URL http://www.ncl.ac.uk/icef/EC_Supplement.htm). The decreasing trend in primary productivity might therefore provide evidence that, in addition to rapid social and economic change, Kahua is also experiencing rapid ecological change. Because we identified the highest changes in primary productivity nearby villages, it seems reasonable to assume that human activities drive the reported changes. This would indeed correspond to the results of a recent extensive survey of perceptions and drivers of change in Kahua (Fazey 
et al. 2007), which observed a rise in the difficulties faced by Kahuan communities indicating increasingly limited access to resources. Focus groups highlighted a reduction in the availability of timber, vines and sago palm leaves for building houses, as well as longer distances required to travel inland to collect such resources (Fazey et al. 2007). They also noted a reduction in availability of sea and river fishes, increased pollution due to sanitation problems, as well as an increasing population in the area. On-ground observations (Fazey et al. 2007) suggest that human activities potentially impacting primary productivity in the area include increasing locally-based logging activities for income generation or building materials, increased intensity of gardening activities, establishment of new settlements and/or the planting of cash crops, especially cocoa in the north-west region of Kahua (Fazey et al. 2007). At this stage we cannot conclude on the precise direct mechanisms and practices that might be driving the patterns reported in this paper. However, work in the region with the Kahua Association suggests that there are powerful sociopolitical and economic processes involved, including a rapidly growing population combined with strong local desires to generate income, lack of explicit appreciation of the value of forests for maintenance and provision of ecosystem services within communities, increasing access to global markets that enables income generating activities, and policies and practices of donor agencies that are facilitating shifts from subsistence to monetary-based economy (I. Fazey, personal communication 2009). This paper also does not allow assessment of the impact of such a primary productivity decrease on forest distribution, biodiversity level or the extent to which ecosystem services necessary for maintaining human livelihoods and wellbeing are being compromised. Four hundred and two known species of amphibians, birds, mammals and reptiles have been formally identified in the Solomon Islands and, of these, $20.9 \%$ are endemic and $11.7 \%$ are threatened (United Nations Common Country Assessment 2002; see also URL http://www.cbd.int). Makira Island is presented as being 'home to more endemic species than any other area in the country' and as possessing 'the most significant remaining block of unlogged rainforest in the Solomon Islands, being of international importance because of its many endemic birds and mammals' (Conservation International 2007). Such levels of biodiversity and endemism underline the urgency of assessing how the reported changes in primary productivity affect species richness, distribution and abundance in the area.

In conclusion, this work constitutes a preliminary analysis and calls for future studies. In particular, our study highlights the need to: (1) assess how accurately remote sensing databased results match field data on the ground; (2) identify the socioeconomic and political drivers of such changes; and (3) evaluate how primary productivity changes affect biodiversity level, ecosystem functioning and human livelihoods. It is indeed not clear how accurately the reported trend in NDVI represents ecological changes (Morissette et al. 2004) in Kahua. As NDVI is very sensitive to cloud cover, it generally cannot discriminate between different vegetation types, and in tropical regions where canopy cover is dense the linear relationship between NDVI and primary productivity is weaker (Hoare \& Frost 2004; Pettorelli et al. 2005; Xiao et al. 2006). These constraints might potentially lead to underestimated vegetation change occurring in the Kahua region. Apart from field studies which may be conducted to assess vegetation change at the species and community level, other remote sensing approaches, if possible, may be adopted; for example, Landsat imagery might help mapping potential deforestation at a c. $20 \mathrm{~m}$ scale (Tucker et al. 2004; Koy et al. 2005; Loveland et al. 2008). However, such mapping involves a preliminary ground-truthing phase and cloud contamination has a greater affect on Landsat data than platforms such as MODIS, since Landsat does not provide frequent images systematically turned into composites (van Leeuwen et al. 2006). Moreover, such an approach cannot provide information on the height or structure of the vegetation, which is required here. Ideally, multiple uncontaminated very high resolution images and LIDAR technology would be the best option to monitor above-ground biomass changes in these regions (Goetz et al. 2009); to our knowledge, such data do not currently exist in the public domain. It is not known what the ecological impacts of these observed changes actually are, such as how human activities affect various ecosystem services and how this is in turn affects the livelihoods and wellbeing of local people. Furthermore, in order to ensure policies for sustainable development are better targeted towards achieving conservation and desired livelihood outcomes, better understanding is needed of the complex and dynamic socioeconomic, demographic and political causes behind the reported changes in primary productivity. Continuous adaptation to change is an important aspect of human-environment relationships (Cliggett $e t$ al. 2007; Reenberg et al. 2008) and is affected by processes operating at different spatial and temporal scales (McLaughlin \& Dietz 2008). Such investigations will therefore inevitably be complex, and will require a range of analytical methods and philosophical or epistemological approaches to address them (Evely et al. 2008; Carpenter et al. 2009).

\section{ACKNOWLEDGEMENTS}

We thank Anne-Beatrice Dufour for her help during the first stages of this work.

\section{References}

Achard, F. \& Estreguil, C. (1995) Forest classification of Southeast Asia using NOAA AVHRR data. Remote Sensing Environment 54: 198-208.

Alcaraz-Segura, D., Cabello, J., Paruelo, J.M. \& Delibes, M. (2009) Use of descriptors of ecosystem functioning for monitoring a national park network: a remote sensing approach. Environmental Management 43: 38-48.

Allen, M.G., Bourke, R.M., Evans, B.R., Iramu, E., Maemouri, R.K., Mullen, B.F., Pollard, A.A., Wairiu, M., Watoto, C. \& Zotalis, S. (2006) Solomon Islands Smallholder Agriculture Study. 
Volume 4, Provincial Reports. AusAID, Canberra, Australia [www document]. URL http://www.ausaid.gov.au/publications/pdf/ solomon_study_vol4.pdf

Baldi, G., Nosetto, M.D., Aragón, R., Aversa, F., Paruelo, J.M. \& Jobbágy, E.G. (2008) Long-term satellite NDVI data sets: evaluating their ability to detect ecosystem functional changes in South America. Sensors 8: 5397-5425.

Bayliss-Smith, T., Hviding, E. \& Whitmore, T. (2003) Rainforest composition and histories of human disturbance in Solomon Islands. Ambio 32: 346-352.

Bonan, G.B. (2008) Forests and climate change: forcings, feedbacks, and the climate benefits of forests. Science 320: 1444-1449.

Bourke, R.M., McGregor, A., Allen, M.G., Evans, B.R., Mullen, B.F., Pollard, A.A., Wairiu, M. \& Zotalis, S. (2006) Solomon Islands Smallholder Agriculture Study, Volume 1. Main findings and recommendations. AusAID, Canberra, Australia [www document]. URL http://www.ausaid.gov.au/publications/pdf/ solomon_study_vol1.pdf

Brookfield, H.C. (1969) Some notes on the climate of the British Solomon Islands. Philosophical Transactions of the Royal Society $B$ 255: $207-210$.

Campbell, J.B. (2007) Introduction to Remote Sensing, 4th Edition. New York, NY, USA: Guilford Press.

Carpenter, S.R., Mooney, H.A., Agard, J., Capistrano, D., DeFries, R.S., Diaz, S., Dietz, T., Duraiappah, A.K., Oteng-Yeboah, A., Pereira, H.M., Perrings, C., Reid, W.V., Sarukhan, J., Scholes, R.J. \& Whyte, A. (2009) Science for managing ecosystem services: beyond the Millennium Ecosystem Assessment. Proceedings of the National Academy of Sciences USA 106: 1305-1312.

Cliggett, L., Colson, E., Hay, R., Scudder, T. \& Unruh, J. (2007) Chronic uncertainty and momentary opportunity: a half century of adaptation among Zambia's Gwembe Tonga. Human Ecology 35: 19-31.

Conservation International (2007) Makira, Solomon Islands [www document]. URL http://biosurvey.conservation.org/ portal/server.pt/gateway/PTARGS_0_127583_136413_0_0_18/ Makira\%20Solomon\%20Islands-2007.pdf

Dahl, A. (2004) UNEP Islands Directory. United Nations Environment [www document]. URL http://islands.unep.ch/isldir.htm

Ebi, K.L., Lewis, N.D. \& Corvalan, C. (2006) Climate variability and change and their potential health effects in small island states: information for adaptation planning in the health sector. Environmental Health Perspectives 114: 1957-1963.

Evely, A.C., Fazey, I., Pinard, M. \& Lambin, X. (2008) The influence of philosophical perspectives in integrative research: a conservation case study in the Cairngorms National Park. Ecology and Society 13: paper no. 52 [www document]. URL http://www.ecologyandsociety.org/vol13/iss2/art52/

FAO (2000) Asia and the Pacific National Forestry Programmes: Update 34. 26. Solomon Islands [www document]. URL http://www.fao.org/docrep/003/x6900e/x6900e0t.htm

Fazey, I., Latham, I., Hagasua, J. \& Wagatora, D. (2007) Kahua Research Preliminary Report: Livelihoods and Change in Kahua, Solomon Islands. Aberystwyth University, Aberystwyth, UK.

Feddema, J.J., Oleson, K.W., Bonan, G.B., Mearns, L.O., Buja, L.E., Meehl, G.A. \& Washington, W.M. (2005) The importance of land-cover change in simulating future climates. Science 310 : 1674-1678.

Goetz, S.J., Baccini, A., Laporte, N.T., Johns, T., Walker, W., Kellndorfer, J., Houghton, R.A. \& Sun, M. (2009) Mapping and monitoring carbon stocks with satellite observations: a comparison of methods. Carbon Balance and Management 4: 1-7.

Goward, S.N. \& Prince, S.D. (1995) Transient effects of climate on vegetation dynamics: satellite observations. Fournal of Biogeography 22: 549-564.

Hoare, D. \& Frost, P. (2004) Phenological description of natural vegetation in southern Africa using remotely-sensed vegetation data. Applied Vegetation Science 7: 19-28.

Holben, B. (1986) Characteristics of maximum-value composite images from temporal AVHRR data. International fournal of Remote Sensing 7: 1417-1434.

Huete, A., Didan, K., Miura, T., Rodriguez, E.P., Gao, X. \& Ferreira, L.G. (2002) Overview of the radiometric and biophysical performance of the MODIS vegetation indices. Remote Sensing of Environment 83: 195-213.

Jensen, J.R. (2007) Remote Sensing of the Environment: An Earth Resource Perspective. Second Edition. Upper Saddle River, NJ, USA: Prentice Hall.

Kerr, J.T. \& Ostrovsky, M. (2003) From space to species: ecological applications for remote sensing. Trends in Ecology and Evolution 18: 299-305.

Koy, K., McShea, W.J., Leimgruber, P., Haack, B.N. \& Aung, M. (2005) Percentage canopy cover - using Landsat imagery to delineate habitat for Myanmar's endangered Eld's deer (Cervus eldi). Animal Conservation 8: 289-296.

Leary, T. (1992) Solomon Islands: state of the environment report. South Pacific Regional Environment Programme, Apia, Western Samoa.

Loveland, T.R., Cochrane, M.A. \& Henebry, G.M. (2008) Landsat still contributing to environmental research. Trends in Ecology and Evolution 23: 182-183.

Markon, C.J. \& Peterson, K.M. (2002) The utility of estimating net primary productivity over Alaska using baseline AVHRR data. International fournal of Remote Sensing 23: 4571-4596.

McLaughlin, P. \& Dietz, T. (2008) Structure, agency and environment: toward an integrated perspective on vulnerability. Global Environmental Change 18: 99-111.

Morisette, J.T., Pinzon, J.E., Brown, M.E., Tucker, C.J. \& Justice, C.O. (2004) Initial validation of NDVI time series from AVHRR, Vegetation and Modis. In: International SPOT 4/5 - VEGETATION users Conference, Antwerp, Belgium [www document]. URL http://www.smaq-life. org/files/techwatch/Earth_Observation_Derived_Information/ Abstracts_-_2nd_VEGETATION_International_Users_Conference.pdf

Mueller-Dombois, D. \& Fosberg, R.F. (1998) Vegetation of the Tropical Pacific Islands. New York, NY, USA: SpringerVerlag.

Neigh, C.S.R., Tucker, C.J., \& Townshend, J.R.G. (2008) North American vegetation dynamics observed with multiresolution satellite data. Remote Sensing of Environment 112: 17491772 .

Pettorelli, N., Vik, J.O., Mysterud, A., Gaillard, J.M., Tucker, C.J. \& Stenseth, N.C. (2005) Using the satellite-derived NDVI to assess ecological responses to environmental change. Trends in Ecology and Evolution 20: 503-510.

Raymond, D.H. \& Wooff, W.G. (2006) Small-scale forest plantations are the key to the future of the Solomon Islands forest industry. International Forestry Reviem 8: 222-228.

Reenberg, A., Birch-Thomsen, T., Mertz, O., Fog, B. \& Christiansen, S. (2008) Adaptation of human coping strategies 
in a small island society in the SW Pacific: 50 years of change in the coupled human-environment system on Bellona, Solomon Islands. Human Ecology 36: 807-819.

Saleska, S.R., Didan, K., Huete, A.R. \& Rocha, H.R.D. (2007) Amazon forests green-up during 2005 drought. Science 318: 612.

Tanre, D., Holben, B.N. \& Kaufman, Y.J. (1992) Atmospheric correction algorithm for NOAA-AVHRR products: theory and application. IEEE Fournal of Geosciences and Remote Sensing 30: 231-248.

Tucker, C.J. (1979) Red and photographic infrared linear combinations for monitoring vegetation. Remote Sensing of the Environment 8: 127-150.

Tucker, C.J., Townshend, J.R.G. \& Goff, T.E. (1985) African land-cover classification using satellite data. Science 227: 369 375.

Tucker, C.J., Grant, D.M. \& Dykstra, J.D. (2004) NASA's global orthorectified Landsat data set. Photogrammetric Engineering and Remote Sensing 70: 313-322.

United Nations Common Country Assessment (2002) Solomon Islands [www document]. URL http://www.un.org.fj/_ resources/un/files/CCA_Solomons.pdf
UNESCAP (2005) Statistical Indicators for Asia and the Pacific [www document]. URL http://www.unescap.org/STAT/ data/statind/pdf/t2_dec04.pdf

van Leeuwen, W.J.D., Orr, B.J., Marsh, S.E. \& Hermann, S.M. (2006) Multi-sensor NDVI data continuity: Uncertainties and implications for vegetation monitoring applications. Remote Sensing of Environment 100: 67-81.

Walker, B. \& Salt, D. (2006) Resilience Thinking: Sustaining Ecosystems and People in a Changing World. Washington DC, USA: Island Press.

Whitmore, T.C. (1969) The vegetation of the Solomon Islands. Philosophical Transactions of the Royal Society B 255: 259.

Wright, S.J. (2005) Tropical forests in a changing environment. Trends in Ecology and Evolution 20: 553-560.

WSSD Working Group (1992) Solomon Islands National Assessment. World Summit on Sustainable Development (Rio +10) [www document]. URL http://www.un.org/esa/ agenda21/natlinfo/wssd/solomonIslands.pdf

Xiao, X., Hagen, S., Zhang, O., Keller, M. \& Moore, B. (2006) Detecting leaf phenology of seasonally moist tropical forests in South America with multi-temporal MODIS images. Remote Sensing of Environment 103: 465-473. 